\title{
William Faulkner as a Philosophical Writer
}

\author{
Iwona Szydłowska \\ https://orcid.org/0000-0003-2728-1263
}

This article raises the problem of philosophical aspects of William Faulkner's works. It is intended first of all to review in brief the place of philosophy in literature and to prove that William Faulkner deserves a special place among philosophical writers such as Kierkegaard, Marcel and Sartre. Although not sufficiently recognized as a philosophical writer, William Faulkner is among those who have successfully introduced philosophical ideas into their novels. This article intends to bear out that Faulkner's novels do not only consider some fundamental philosophical concepts but also open the door to further philosophical debates.

The first, shortest part of this work is a presentation of the philosophical discussion concerning the fusion of philosophy and literature. There, the focus is on the negative and positive approaches to the issue of combining philosophy and literature as represented by such prominent philosophers as Iris Murdoch, Jacquelyne Kegley, Martha Nussbaum and Philip Kitcher.

In its second part, the article presents William Faulkner's philosophical affiliations of interest, which are: metaphysics, linguistics, ethics, religion and existentialism. The conclusion stresses Faulkner's input into philosophy but also indicates different fields his novels open for further philosophical investigation.

Keywords: literature, philosophy, Faulkner, metaphysics, linguistics, ethics, religion, existentialism

IWONA SZYDŁOWSKA, MA in English Philology, a postgraduate student in the Department of Social Sciences at the University of Gdansk (Institute of Philosophy); address for correspondence: Wydział Nauk Społecznych, ul. Jana Bażyńskiego 4, PL 80-309 Gdańsk; e-mail: i.partyka@wp.pl 


\section{Fusion of philosophy and literature}

The question of the position of artists among philosophers takes us back to the times of the Platonic Greece, where the debate on the mutual relationship between philosophy and literature was touched off. Although modern philosophy has found more warm feelings towards its other humanistic disciplines such as literature, the discussion about the place of writers among philosophers still seems to blossom.

Every endeavor to study a literary work through the perspective of philosophical concepts requires a peculiar fusion of literature and philosophy. For the author of this article, the idea of mutual contribution of literature and philosophy is obvious and has its legacy in the philosophical hermeneutics of Gadamer. He was one of the first to actually introduce a holistic approach to a literary work rooted in philosophy and sanctioned the interaction between both disciplines. As much as one may agree with the idea of fusion of literature and philosophy as doubly fruitful, there are opponents who perceive any marriage between both disciplines as incompatible.

One of the most ardent adversaries of such fusion is the writer and philosopher Iris Murdoch, who does not ascribe any major role to philosophy in literature. Hers is the central argument that literature tends to conceal, rather than reveal, a philosophical message: "You said a moment ago that the aim of philosophy is to clarify whereas the aim of literature, very often, is to mystify" ${ }^{1}$. In her conversation with Bryan Magee, Murdoch explains that, in her view, philosophy and literature are completely separate disciplines, and she rejects any claims for a common ground between them. As she says, they are equipped with completely different tools of conveying their truths. Besides, she perceives philosophy as an abstract and systematic science, without any relevance to human experience ${ }^{2}$.

A more positive view on the fusion between philosophy and literature has been presented by Jacquelyn Kegley. In her essay “The End of the Road: The Death

\footnotetext{
${ }^{1}$ Iris Murdoch, "Literature and Philosophy: A Conversation with Bryan Magee," in Existentialists and Mystics: Writings on Philosophy and Literature, ed. Peter Conradi (London: Penguin Books, 1999), 5.

${ }^{2}$ One can learn about Murdoch's views on the subject from a conversation she held with the philosopher and broadcaster Bryan Magee "Literature and Philosophy: A Conversation with Bryan Magee," $3-30$.
} 
of Individualism" Kegley argues that artistic creativity and rational discourse working together can produce even more philosophically convincing literary work. As she mentions, it is good when the author "places reason and imagination in contention, suggesting that either faculty in isolation is inadequate in dealing with human experience"3.

A very interesting discussion is currently ongoing regarding the extent to which the barrier between philosophy and literature can be erased. The prominent philosopher Stanley Cavell, for one, analyzing Shakespeare's tragedies, argues that philosophy and literature can successfully fuse. He writes: "I become perplexed in trying to determine whether it is to addicts of philosophy or to adepts of literature that I address myself when I in effect insist that Shakespeare could not be who he is - the burden of the name of the greatest writer in the language, the creature of the greatest ordering of English - unless his writing is engaging the depths of philosophical preoccupations of his culture"4. Philosopher Martha Nussbaum has gone the furthest in insisting that conventional distinction between philosophy and literature will have to be modified or even abolished. She writes: "For I was finding in the Greek tragic poets a recognition of the ethical importance of contingency, a deep sense of the problem of conflicting obligations, and a recognition of the ethical significance of the passions, that I found more rarely, if at all, in the thought of the admitted philosophers, whether ancient or modern"5. By referring to the Greek tragic poets she stresses their role in evoking proper emotions which in turn lead to recognition of the ethical significance of a given problem. The assumption that literary style is adequate for presenting deep, important and complex ethical concerns is part of her overall argument in support of everlasting marriage of philosophy and literature.

Whether literature should be a part of moral philosophy, however, is not as obvious for Lamarque and Olsen. In their book Truth, Fiction and Literature they try to prove that the dilemma whether literature should be a part of moral philosophy "would be uninteresting from the point of view of literary aesthetics since it

\footnotetext{
${ }^{3}$ Jacquelyn Kegley, "The End of the Road: The Death of Individualism," in Philosophy and Literature, ed. Allen Phillips Griffiths (Cambridge: Cambridge University Press, 1984), 115.

${ }^{4}$ Stanley Cavell, Disowning Knowledge in Seven Plays of Shakespeare (Cambridge: Cambridge University Press, 2003), 2.

${ }^{5}$ Martha Nussbaum, Love's Knowledge (Oxford: Oxford University Press, 1990), 14.
} 
makes no claims about any systematic relationship between literature and philosophy"6.

While Nussbaum, Lamarque and Olsen discuss ethical issues, Philip Kitcher concentrates on the questions developed by Schopenhauer and Nietzsche, whose main aim was to find out how to live. His stance is especially precious as he himself is a philosopher of science, more involved, until recently, in the philosophical ideas of Kuhn than in literature. However, in 2013 Kitcher took up the question of philosophy and literature in his book Deaths in Venice: The Cases of Gustav von Aschenbach. There he advances what he calls the broader conception of philosophy based on "three grades of philosophical involvement that literary, or musical, work may manifest" his claim that involvement with literature can indeed have a lasting impact on the readers (as opposed to a skeptic's claim that this influence can at best be episodic) and that conclusions readers reach can be trustworthy and can have as serious a standing as one represented by philosophical science.

Even a superficial look at the discussion concerning the role of literature in a philosophical discourse makes it easy to notice that it is not the end of the debate. Selected stands have been mentioned only to demonstrate the complexity of this argument. Although a total fusion of philosophy and literature is neither necessary nor reasonable, they still have common goals. Some of the most fundamental among them are to not only show a man how to live but also to introduce him to his own metaphysical, linguistic, existential and ethical reasoning.

\section{Philosophical ideas in William Faulkner's works}

The reason Faulkner's philosophical input in literature has not been sufficiently recognized is not because his works lack any philosophical background but because he conveys his philosophical message in an implicit way. He does not, like for instance Mann, put his message into his characters' mouths and make them deliver their philosophical wisdom in front of the reader. Faulkner is more tactful

\footnotetext{
${ }^{6}$ Peter Lamarque, Stein Haugom Olsen, Truth, Fiction, and Literature: A Philosophical Perspective (Oxford: Oxford University Press, 1994), 389-390.

${ }^{7}$ Philip Kitcher, Deaths in Venice: The Cases of Gustav von Aschenbach (New York: Columbia University Press, 2013), 13.
} 
with his characters, which does not change the fact that he has hidden a lot of philosophical questions in his works. Iris Murdoch once observed that philosophy is only "a plaything of the writer". In Faulkner's hand this plaything, however, changes into a philosopher's stone that makes nearly each of his novels a substantial philosophical treatise of extreme complexity. And as it is true that Faulkner's critics have focused on such isolated philosophical issues as absurdity, time, or destiny, the majority of Faulkner's criticism concentrates on the issues of psychology, identity, race or - most recently - gender. The author of this article is not aware of anyone who would look at Faulkner's works from a more philosophical perspective, not to mention singling out the philosophical problems Faulkner embedded in his novels. Even though one may find some isolated critical works on Faulkner's metaphysics, the topic taken up by Sartre in the 1940s, ethics or religion, his existential input in the world of humanism seems to be absolutely neglected. It is doubly surprising if we consider that Faulkner was the forefather of this philosophical movement, which may be considered a real precedence in the world of philosophy.

This work, therefore, aims to introduce Faulkner as a philosophical writer and point at the main philosophical aspects of his works.

\section{Time and metaphysics}

First deliberations about the nature of time go back to ancient Greece and Plato, who considered time as being substance-like, with time as eternal power measured by heavenly motion. After him, Aristotle, Leibniz, Kant, but also modern philosophers struggled with the idea of time, which had a tremendous impact on literature. When we hear about experiments with time in literature, we automatically think about Proust, Joyce and Virginia Woolf.

Although it is true that they were the ones to begin playing with the notion of time and the stream of consciousness technique, William Faulkner was the first writer who not only used the stream of consciousness but also incorporated the modern notion of time into the very structure of his novels, which made him the greatest metaphysician of our times. One of the first critics to notice that

\footnotetext{
${ }^{8}$ Murdoch, "Literature and Philosophy," 19.
} 
Faulkner's metaphysics is similar to Bergson's was Walter J. Slatoff. In his Quest for Failure he writes: "Like Bergson he [Faulkner] often tends to view experience as a state of the whole being or of the self and to conceive of the self as an indivisible internal process which can only be intuited"9. A look at Loic Bouvard's interview with Faulkner from 1968 reveals that Slatoff was not mistaken. There, Faulkner admits that he was influenced by Flaubert and Balzac, "and by Bergson, obviously"10.

Bergson expressed his view of time chiefly in Time and Free Will (1889), Matter and Memory (1896), and Creative Evolution (1907). He asserted the popular conception of time as a medium in which our impressions and emotions are arranged in the same kind of order that we find in space. It consequently gave rise to a hypothesis that consciousness exists in a different medium than that in which material objects exist because one state of consciousness does not necessarily preclude another, and even successive states of consciousness are interdependent. Pure duration, or durée as Bergson calls it, is a state in which we do not separate the present from the past or from the future, which implies that the nature of time can be circular. And it is this very notion Faulkner has in mind when he is talking to Loic Bouvard: “There isn't any time, he replied. In fact I agree pretty much with Bergson's theory of the fluidity of time. There is only the present moment, in which I include both the past and the future, and that is eternity. In my opinion time can be shaped quite a bit by the artist; after all, man is never time's slave"11. The most vivid application of Bergsonian philosophy in Faulkner is to be found in The Sound and the Furywhere, as Margaret Church states in her critical studies about time in fiction, "both [Ben and Quentin] share a sense of duration,"12 the very idea Bergson expresses in his Time and Free Will ${ }^{3}$.

\footnotetext{
${ }^{9}$ Walter J. Slatoff, Quest for Failure: A Study Of William Faulkner (Ithaca: Cornell University Press, 1960), 242.

${ }^{10}$ James B. Meriwether, Michael Millgate (eds.), Lion in the Garden: Interviews with William Faulkner, 1926-1962 (New York: Random House, 1968), 72.

${ }^{11}$ Ibid., 70.

${ }^{12}$ Margaret Church, Time and Reality: Studies in Contemporary Fiction (Chapel Hill: The University of North Carolina Press, 1963), 234.

${ }^{13}$ Arjen Kleinherenbrink, “Time, Duration and Freedom - Bergson's Critical Move Against Kant," Diametros, 2014, no. 39: 203-230, doi: 10.13153/diam.39.2014.572

Although the author explains Bergsonian concepts with reference to Kant, the article contains many fragments from Time and Free Will which are not only quoted but also commented on by Kleinheren-
} 
In Faulkner's works the question of time gives rise to many other philosophical issues. One of them would be the issue of consciousness and the relation between memory and perception, so perspicaciously presented, for instance, in $A s$ I Lay Dying, where the novelist presents various individual perceptions of the same event, namely the death of the characters' mother. Such an approach to his novelistic task gives rise to a whole spectrum of phenomenological issues among which time and consciousness seem to be of the greatest importance.

Sartre was one of the first to direct a broader attention to the Bergsonian way in which Faulkner approached time. In his essay "On The Sound and the Fury" not only did he analyze the way Faulkner manipulated the time but he also came to the conclusion that time is a source of Faulkner's metaphysics. As he wrote: "[...] a novelistic technique always relates to the novelist's metaphysics. The critic's task is to identify the latter before evaluating the former. It is blindingly obvious that Faulkner's metaphysics is metaphysics of time"14. Sartre's observation not only directed critics' attention to the question of time in Faulkner's works but also introduced Faulkner to the pantheon of great metaphysicians. As Nabil Boudraa observes: "For Faulkner, man is the sum of his past. The past is with us always and at every moment. 'The past is never dead,' says his character, Gavin Stevens, in Requiem for a Nun. Faulkner's obsession with the past comes alive at different levels in his fiction. For Malcolm Cowley, even Faulkner's long sentences carry this burden of containing both the present and the past" ${ }^{15}$. What Sartre did not like about Faulkner's treatment of time was the fact that by negation of temporality and by making the past overshadow his characters, he stripped time of its future and therefore of its dimension of freedom. Nabil Boudraa in his article "William Faulkner and the French-Speaking World" writes: "However, Faulkner's universe, which is always oriented towards the past, contradicts Sartre's openness to the possibilities of the future"16. That is why ending his essay on Faulkner's

brink. As he not only analyzes selected parts of Time and Free Will but also reconstructs the consequences regarding freedom, his analysis is particularly fruitful: if adapted to Faulkner's works, it allows one to observe further consequences for the analysis of the concept of freedom in his novels.

${ }^{14}$ Jean-Paul Sartre, ed. Ronald Aronson and Adrian van den Hoven, We Have Only This Life to Live: The Selected Essays of Jean-Paul Sartre, 1939-1975 (New York: New York Review Books classics, 2013), 18.

${ }^{15}$ Nabil Boudraa, "William Faulkner and the French-Speaking World," International Journal of Language and Literature, December 2014, no. 4: 112, DOI: 10.15640/ijll.v2n4a6.

${ }^{16}$ Ibid. 
Sound and the Fury, Sartre wrote: "I love his art; I do not believe in his metaphysics"17.

This statement, however, does not seem to solve Faulkner's metaphysics. Even if Sartre reproaches Faulkner for depriving his characters of any future, he misses the point that at the heart of Faulkner's concern, instead of chronological order, is the adoption of the emotional order. It is not the chronology set by mechanical time of clocks and watches but the one established by the memory of the character's heart.

It is tempting to suggest that although Sartre criticized Faulkner for situating his narrative in the past, not only did he not pay heed to the author's intentions, but he also deprived Faulkner's work of any historical and social factuality.

Even though the question of Faulkner's metaphysics has not been discussed much by literary critics, the Sartrean interpretation of The Sound and the Fury does have its modern opponents. In his article "Sartre on William Faulkner's Metaphysics of Time in The Sound and the Fury," Justin Skirry addresses the notion of Faulknerian metaphysics. In his work he opposes Sartre on three points. Firstly, he tries to prove that "his [Faulkner's] novel's ordering is purposeful despite its apparent lack of order as Sartre correctly pointed out"18. In the subsequent part of his article, Skirry convincingly proves that Faulkner's ordering is a "phenomenological ordering." Contrary to Sartre's conclusion, Skirry establishes that "[...] some of the character's phenomenologies of time include the present, and therefore are not the past only" ${ }^{19}$. Skirry's third thesis goes even further when he argues that "the future is present to the reader as an absence in the novel"20.

It may be worthwhile to add one more observation to what Skirry has noticed. In The Sound and the Fury there is one character who perfectly knows how to interpret her defective kitchen clock, Dilsey - the black maid. As Cleanth Brooks observes: "Her ability to make sense of the clock is simply one aspect of

\footnotetext{
${ }^{17}$ Sartre, Aronson and Hoven, We Have Only This Life to Live, 25.

${ }^{18}$ Justin Skirry, "Sartre on William Faulkner's Metaphysics of Time in The Sound and the Fury," Sartre Studies International 7, no. (2001): 11, https://www.jstor.org/stable/23510954 (accessed January 10, 2018).

${ }^{19}$ Ibid., 15.

${ }^{20}$ Ibid.
} 
her ability to make sense of past, present, and future"21. That might find its resonance in Faulkner's words about Dilsey: "I had already gone on to night and the bedroom and Dilsey - Dilsey, who was trying to hold the crumbling household together, already trying to cleanse with the sorry by blow of its soiling that body, flesh, whose shame they prophesied, as though she already saw the dark future and what she was to do - with the mud-stained [sic] drawers scrubbing the naked behind of that doomed and courageous and tragic little girl. Then the story was complete, finished. There was Dilsey to be the future, to stand above the fallen ruins like a ruined [sic] chimney, growing gaunter and gaunter with the years, patient and indomitable, and Benjy to be the past. That's why he is an idiot: so that like Dilsey he can be impervious to the future, though unlike her, by refusing to accept it at all"22. William Faulkner's words about how he perceived the figure of Dilsey throw a different light on the metaphysical interpretation of his novel. As Cleanth Brooks notes: "Perhaps a more accurate way of stating the truth that inheres in Sartre's view is to say: man's very freedom is bound up with his sense of having some kind of future"23.

Undeniably, it is an interesting issue to consider, one which may constitute the core of some further philosophical analysis of Faulkner's works. One thing is certain: all those different critical voices about Faulkner's metaphysics (the voices which, as a matter of fact, have yet to agree to a compromise) undoubtedly prove that there is still much that can be said about the issue - which is only one of many philosophical phenomena that Faulkner considered in his works.

\section{The philosophy of language}

Although we lack evidence that Faulkner studied any of the twentieth-century philosophers of language, he undeniably found that sphere of philosophical thought particularly close. He approaches the issue of language in a more or less

\footnotetext{
${ }^{21}$ Cleanth Brooks, "Five Perspectives in The Sound and the Fury," in Readings on William Faulkner, ed. Clarice Swisher (San Diego: Greenhouse Press, 1998), 107.

${ }^{22}$ Philip Cohen and Doreen Fowler, "Faulkner's Introduction to The Sound and the Fury," American Literature, 62, no. 2 (June 1990): 281, DOI: 10.2307/2926916.

${ }^{23}$ Brooks, "Five Perspectives in The Sound and the Fury," 107.
} 
direct way, pondering on the epistemological nature of meaning as well as its functionality.

As early as in his second novel Mosquitoes, first published in 1927, concurrently to his extensive exploration of art and the role of the artist, Faulkner contemplates the issue of language. As Gary Harrington notes in his critical essay Mosquitoes. "Every character in Mosquitoes explicitly or implicitly evinces a different attitude towards language and each may be placed on a scale the opposites extremes of which are Talliaferro's belief that the word is all and Gordon's dismissal of language as irrelevant and insubstantial"24. Harrington points out that Faulkner hints at a correlation between language as self-expression and self-definition. As Harrington rightly observes, Faulkner in this novel teases the reader with different attitudes to the function of language, one of which may be this of denial of the essential difference between fiction and reality, and "in so doing futilely attempts to span the unbridgeable gap between re-presentation and presence"25.

It cannot be denied, however, that it was with his creation of retarded Benjy's language of emotional expression that Faulkner achieved real mastery of his workshop, provoking this way a whole range of philosophical-linguistic associations. It is in the monologues by idiot Benjy from The Sound and the Fury that Faulkner displays to us a language that, ironically, cannot be translated or interpreted sensibly without irreducible loss. Faulkner's language is a language of paradox, of nonsense masquerading beautifully as sense. When this language works, it generates the powerful illusion that we can make sense of the living world.

One of the critics who have recently approached the same subject is Rupert Read. In his essay "Wittgenstein and Faulkner's Benjy" he tackles the problem of the paradox of language in Faulkner's novel. Then we have Nancy Blake who in her article "The Word as Truth or Delirium: Faulkner's As I Lay Dying" has also taken up the problem of language and meaning. As she notes: “Faulkner's tale dramatizes Wittgenstein's aporia which affirms that contradiction is the breaking point of a proposition, the crack through which the real emerges. Contradiction is the means the discourse uses in order to signify its impotence when faced with

\footnotetext{
${ }^{24}$ Gary Harrington, "Mosquitoes," in Faulkner's Fables of Creativity: The Non-Yoknapatawpha Novels (Houndmills, Basingstoke / London: The Macmillan Press Ltd, 1990), 25.

${ }^{25}$ Ibid., 29.
} 
the real"26. Although Blake in her essay mainly takes a feminist approach to the language, it only proves how linguistically rich Faulkner's works can be and how many dimensions of language we can find there.

Finishing this brief analysis of the philosophical aspect of linguistic connotations in Faulkner's novels, let us now have a look at the last but rather important aspect of Faulknerian philosophical input in this field. As is commonly known, Faulkner was deeply rooted in the Southern culture where language, with all its dialects and differences, became an additional source of fascination and deeper analysis for him. As Olga W. Vickery notes: "He [Faulkner] probes and traces its [language's] various forms in an effect to reveal why and how such a foundation is necessary in order for communication through language to be effected"27. By a closer look at different dialogues in such novels as Light in August or Sanctuary, the novels in which Faulkner most profoundly presented the black and white dichotomies, Vickery rightly observes that "some community of experience seems to be the prerequisite for communication"28. It unavoidably leads to a concomitant conclusion that there is no direct relationship between the word and its referent. As she writes: "The object is itself involved in the process of change and the word is continually acquiring additional connotations, personal, social, and historical, in order to make it conform to the speaker's view of the object"29. By touching on such problems as language and its referential potentialities, Faulkner not only stressed the epistemological search for truth in language but also tried to render the truth of man. The writer created his characters in such a way that not only was he able to present the relationship of the concept of the language to reality, but also to show man's constant struggle on his way to the truth.

\footnotetext{
${ }^{26}$ Nancy Blake, “The Word as Truth or Delirium: Faulkner's As I Lay Dying," Revue belge de philologie et d'histoire, 63, no. 3 (1985): 554, DOI: 10.3406/rbph.1985.3513.

${ }^{27}$ Olga W. Vickery, "Language as Theme and Technique," in The Novels of William Faulkner: A Critical Interpretation (Baton Rouge: Louisiana State University Press, 1964), 267.

${ }^{28}$ Ibid.

${ }^{29}$ Ibid.
} 


\section{Faulkner and ethics}

Susan Sontag, interviewed by Bellamy, says: "When I said 'Every style embodies an epistemological decision,' I did not mean that everybody has an idea of the relation of fiction to life. I think that everybody has implicitly an idea about what is most interesting to talk about, to emphasize, because any description, any narration, any discourse is a radical selection of certain elements to the exclusion of many other elements" ${ }^{\prime 30}$. This epistemological decision, as Sontag calls it, is in fact tantamount to the writer's ethical involvement. As she has noticed, he selects some topics and by this very fact becomes the creator of ethical order. If he is not a propagandist, which Faulkner certainly was not, he offers his reader a set of different but limited ways of interpretation. William Faulkner knew about it and although he handled it with a mastery of a genius, he always worked on some old, tested material. He admits it himself: "That to me, the writer is simply trying to use the best method he possibly can find to tell you a true and moving and familiar old, old story of the human heart in conflict with itself for the old, old human verities and truth, which are love, hope, fear, compassion, greed, lust. [...] he's simply trying to tell you the same story of the human heart in conflict with itself for the eternal verities which haven't changed too much since man first found how to record them" ${ }^{31}$.

In an address delivered at Junior College on 8 June 1953, Faulkner also referred to "the philosophers and artists, the articulate and grieving which have reminded us always of our capacity for honor and courage and compassion and pity and sacrifice" as being "avatars of [Satan's] rebellious and uncompromising pride" ${ }^{32}$.

Even a beginner reader of Faulkner will notice his familiarity with the Old and New Testaments. He did not hesitate to use biblical quotes and narratives to make them a background for his stories. And although he used the Bible abundantly, he did so with such virtuosity that it never became a tool of voicing, no

\footnotetext{
${ }^{30}$ Susan Sontag, Leland A. Poague, Conversations with Susan Sontag (Jackson: University Press of Mississippi, 1995), 41.

${ }^{31}$ William Faulkner, Milton T. Inge, Conversations with William Faulkner (Jackson: University Press of Mississippi, 1999), 188.

${ }^{32}$ Harrington, "Mosquitoes," 118.
} 
matter how cryptically, any moral judgments. On the contrary, Faulkner's biblical connotations only gave additional dimension to his stories and novels.

Let us have a look, for example, at one of his earliest novels, Light in August, which begins with the story about Lena Grove, a pregnant young woman from Alabama sitting beside a road in Mississippi. By contrasting her with another hero, Joe Christmas, a mulatto murdered in a racist rage, Faulkner moves towards a larger conflict between good and evil, life and anti-life, the spirit and the birth as well as the murderous abstractions and obsessions which drive most of his characters. In his critical assessment of Light in August, Joseph Reed wrote: "A colleague once said to me that he liked Light in August because it was the greatest study he knew of the origins of evil. I agreed at the time and still agree, but more and more wonder which origins of evil" ${ }^{33}$. Although ethics, as mentioned before, is one of the main issues in Faulkner's works, its multi-dimensional treatment not only makes the philosophical discussion possible but also often leads to disputes, even among the critics. Let us take one of Faulkner's greatest connoisseurs - Malcolm Cowley. In his introduction to Portable Faulkner, he writes: "There is not one of Faulkner's characters," says Andre Gide in his dialogue on The New American Novelists, "who, properly speaking, has a soul"; and I think he means not one of them, in the early novels, exercises the faculty of conscious choice between good and evil" ${ }^{34}$. Cowley wrote it in 1945 . However, in his later edition of the volume, he came back to the question of good and evil in Faulkner. After a short recapitulation of his previous view, he wrote: "The sense of doom and outrage that brooded over the early ones [novels] has been replaced by pity for human beings, even the worst of them ["The poor sons of bitches," Gavin Stevens says, "They do the best they can"] and by the obstinate faith expressed in the Nobel Prize address "That man will not only endure: he will prevail" - all this combined with more than a touch of old-fashioned sentiment" ${ }^{35}$. As we can see, not only did Faulkner in his works bring ethical issues to light, but he also did it in such a way as to open a door to further philosophical investigation. And ethical problems, especially

\footnotetext{
${ }^{33}$ Joseph W. Reed Jr., "Light in August," in William Faulkner (Modern Critical Views), ed. Harold Bloom (New York/Philadelphia: Chelsea House Publishers, 1986), 69.

${ }^{34}$ Malcolm Cowley, "Introduction," in The Portable Faulkner (New York/London: Penguin Books, 2003), xxii.

${ }^{35}$ Ibid.
} 
in the case of such equivocal writers as Faulkner, are issues of the highest respect, with an outstanding place in the hierarchy of philosophical interests.

Over and over in various ways, through the development and frequent failures of his characters, through the very methods in which he manipulates time and painfully and partially discloses the truth of his vision, Faulkner seems to be highlighting certain essential ethical truths about the human condition. He wrote about American South as he experienced it in twentieth-century America: fragmented, tortured, frequently absurd, using language idea and concept not to create a meaningful area of freedom and brotherhood, but as a way of exerting pressure and exonerating one's cruelties.

By demonstrating how our illusions and lack of ethical insight can kill others, but also ourselves, Faulkner indicated how they can destroy our potential for growth as human beings and our capacity to love. For that is after all, according to Faulkner, what we should be about in the world of partial, imperfect and misinterpreted knowledge: as he tells us in Light in August and shows us over and over again with Disley and Jewel, with Harry and Byron, it is God's role to know everything - man's role is to love. And that is only part of the Faulknerian ethics. The second, perhaps even more illuminating is that message that he strives to carry through all his novels, this strong belief in the miraculous possibility of good in the world of corruption and evil.

\section{Faulkner and religion}

When giving advice to young writers, Faulkner said: "You are going to write about truth: man as he comes into conflict with his heart" ${ }^{36}$. Commenting on this well-known Faulknerian phrase, George C. Bedell observed in his comparative study of Faulkner and Kierkegaard: "[...] "the problem of the human heart in conflict with itself," which is Faulkner's way of talking about what Kierkegaard considers the religious writer. It simply means that he saw the agony and joy of life against the backdrop of eternity" ${ }^{37}$.

\footnotetext{
${ }^{36}$ Faulkner, Inge, Conversations with William Faulkner, 163.

${ }^{37}$ George C. Bedell, Kierkegaard and Faulkner: Modalities of Existence (Baton Rouge: Louisiana State University Press, 1972), 7.
} 
Bedell's observation is absolutely right, which finds its confirmation in Faulkner's own words. In one of his interviews Faulkner explains what he actually means by those "truths of heart," and although he does it a little differently than Bedell, they both generally mean the same: "It is man's knowledge that at bottom he is not very brave, that he is not very compassionate, but he wants to be - his conscience - call it what you will, call it God, but he wants to be better than he is afraid that he might be, that he might fail, yet he still tries" ${ }^{\prime 3}$. In a similar manner, commenting on other contemporary authors, Faulkner opinioned that The Old Man and the Sea is Hemingway's best work because "he found God ... Before, he was working in a vacuum" ${ }^{39}$.

It seems that Faulkner himself had found God in his own writing. It seems he created his characters in order to have familiar companions with whom he might start his own quest for some eternal truths about human life. No matter whether it is Go Down Moses, Light in August or The Sound and the Fury, nearly each of his works carries a mark of the writer's concern with God and faith. Few modern writers have employed so many biblical allusions, stories and legends in their works as Faulkner has done. Even a superficial look at the characters of just one novel, Light in August, will help us understand that religion occupies a fundamental position in Faulkner's works: Joe Christmas, whose very name suggests references to the figure of Christ, McEachern with his strict Calvinistic beliefs, Reverend Hightower, or eventually Lena Grove, whom many critics have identified as the incarnation of the Virgin Mary. By accumulating such a varied conglomeration of different religious attitudes and beliefs, Faulkner shows his deep concern about religion and its spiritual role in the condition of humankind.

Moreover, although Faulkner populates his works with many protagonists whose atheism is obvious, he very often suggests that there may be some supernatural force at work influencing their lives. Such is the case with Dilsey from The Sound and the Fury, whose strong faith is presented in contrast to the morally dilapidated Compson family. As Cleanth Brooks observes: “Dilsey's goodness is no mere goodness by, and of, nature, if one means by this a goodness that justifies a faith in man as man. Dilsey does not believe in man; she believes in God [...]"40.

\footnotetext{
${ }^{38}$ Faulkner, Inge, Conversations with William Faulkner, 156.

${ }^{39}$ Ibid.

${ }^{40}$ Brooks, "Five Perspectives in The Sound and the Fury," 110.
} 
Although Dilsey is not a saint herself, her strong religious involvement seems sincere. It is this sincerity and real devotion to religion, no matter which, that Faulkner tries to advocate in his novels. If he ever undercuts either religion or belief in God, it is not the religious faith he stands against but only the way religion is practiced by some types of people.

It is true that Faulkner utilized the Christian story, just like in A Fable, as a myth, but he did so to tell us something about our universal condition as humankind. Even in the above-mentioned novel where Faulkner uses a New Testament story as a mythical background, there is no doubt he wants to convey a New Testament message that "So long as there is belief in the hope of salvation, the lamb in man contends with the wolf"41.

Although Faulkner did not express his religious concern in such a straightforward way as Kierkegaard or Marcel, his input into discussion about the place of God in human life is no less important. He proved it by giving his characters the right to speak about their own intimate relationships with God. The writer did not only concentrate on his main protagonists such as Sutpens or Sartoris. Significantly, he favored seemingly minor characters of great faith such as Dilsey or Lena, who "stand above the fallen ruins of the family like a ruined chimney, gaunt, patient and indomitable"42 to give proof to human invincibility.

\section{Faulkner and existentialism}

The first French critical appreciation of Faulkner's work was written by a French professor of literature Maurice Coindreau on 1 June 1931 in La Nouvelle Revue française. In 1930, a student of Coindreau at Princeton introduced him to As I Lay Dying, a novel by William Faulkner, who was then a little-known novelist from Mississippi. Coindreau was impressed by the book and undertook its translation to French. He continued to write critical essays on the author's work, helping to popularize Faulkner in France. It was not earlier than in 1937 that Coindreau, having accepted Faulkner's invitation to visit his home in Rowan Oak,

\footnotetext{
${ }^{41}$ Edmond L. Volpe, A Reader's Guide to William Faulkner: The Novels (Syracuse, NY: Syracuse University Press, 2003), 288.

${ }^{42}$ Cohen, Fowler, "Faulkner's Introduction," 281.
} 
wrote the first draft of his translation of The Sound and the Fury. The novel became much admired by Sartre who wrote a short but lucid analysis on the conception of treatment of time - "William Faulkner's Sartoris" (1939).

It is worth noting that writing the novel took Faulkner three years. It means that he began implementing his philosophical ideas about consciousness, time, and the nature of man about the year 1927. As early as then, Faulkner already had a vision of the world where his investigation into the human condition on a universal level shared a great deal with French existentialism. One may wonder how it is possible if Sartre's flagship works in philosophy, such as Being and Nothingness (1943) and Existentialism is a Humanism (1946) were written many years after Faulkner had published The Sound and the Fury in the United States. How had Faulkner managed to incorporate all the existential ideas in his work before they were actually articulated? And a whole bundle of them at that. The answer is obvious: it was Faulkner who inaugurated the appearance of existentialism as a philosophical movement. He fiddled with not only the field of consciousness but the world of objects as well, just like in As I Lay Dying where the coffin becomes the central figure in the novel. It becomes an important role of an individual and his search for freedom, which was most probably best pictured in such works as The Wild Palms and Sanctuary.

What is most striking in Faulkner's novels is their close proximity to life. Nearly all of his characters, in majority of cases simple rural men, are rooted in their lives through a lively narration whose vibrant tempo keeps them in constant motion. Richard P. Adams in his essay "Faulkner's Use of Motion as Metaphor" notes: "Faulkner therefore is not trying to formulate experience in any direct or logic way. He is trying to organize impressions of speed and energy to build the most intense possible concentrations of force, and then to confine them in the most tightly blocked possibility situations" ${ }^{\text {"43 }}$. Action, not thought, is the starting impulse of human existence. In this very sense "Man first exists, encounters himself, surges up in the world - and defines himself afterwards" ${ }^{4}$. Sartre's words which are the application of the existential rule that "existence precedes essence,"

\footnotetext{
${ }^{43}$ Richard P. Adams, "Faulkner's Use of Motion as Metaphor," in Readings on William Faulkner (Greenhaven Press Literary Companion to American Authors), ed. Clarice Swisher (San Diego: The Greenhaven Press, 1998), 55.

${ }^{44}$ Jean-Paul Sartre, Existentialism and Humanism, trans. Philip Mairet (London: Methuen, 2007), 30.
} 
published in 1946, only defined what Faulkner had been practicing in his prose for at least thirty years prior. No wonder "French authors, such as Jean-Paul Sartre, Albert Camus and Andre Malreaux, find in Faulkner's fictional work resonance to their own philosophical ideas $[\ldots]^{{ }^{* 45}}$. This importance of physical action as a crucial fictional device in Faulkner's fiction, as well as all the other features already mentioned, conclusively establish Faulkner as an absolute founder of the existential philosophy. One can say that, for once, the writer has become the teacher of philosophers, or repeat after Walter Kaufmann: "In the end, Rilke, Kafka and Camus pose a question, seconded by Dostoevsky, Sartre's plays and fiction: could it be that at least some part of what the existentialists attempt to do is best done in art and not in philosophy?"46. Taking into account that Kaufmann is the professor not of literature but philosophy makes it even more resonant and thought-provoking. Without a doubt, William Faulkner is one of the writers who have not been fully appreciated in this respect. It would be an exaggeration to say that he is a better philosopher than Sartre and others; however, he gives no less attention to the problems they also raised and endorsed as their own philosophical mark.

One thing is certain: just like Sartrean existence preceded essence, Faulkner's involvement in existentialism, absurd as it may sound, preceded the very birth of this philosophical movement. This very fact should be sufficient reason to honor this great writer with a decent analysis of the philosophy that he incorporated in his novels forever.

Faulkner did not trust the truths of reason as the first and most important factor in a creative process of writing. He used to repeat again and again that "heart knows better than mind," making the latter only a transmitter of the writer's intuition. Not only did he prove that artistic intuition can be a fantastic source of philosophical ideas, but he also showed that philosophy experienced in a fictional manner may still be philosophy. To quote Kaufmann again: "Could it be that at least some part of what the existentialists attempt to do is best done in art and not in philosophy?" Not to deprecate philosophy, the author of this article believes that yes - in some aspects writers can be equally good philosophers. What one may especially appreciate about Faulkner is that not only did he slip many philosophical problems into his prose, but he also pushed open new doors

\footnotetext{
${ }^{45}$ Boudraa, "William Faulkner and the French-Speaking World," 1.

${ }^{46}$ Walter A. Kaufmann, Existentialism from Dostoevsky to Sartre (New York: Plume, 2004), 49.
} 
for further generations. Especially now, when some old misconceptions of race, religion and the limits of human freedom reappear, Faulkner's philosophical message should be read with special care and concern. One thing is certain: Faulkner's devotion to the problems of "human heart" and its place in the modern world make him not just a great philosopher, but also one of the greatest humanists of our times.

\section{References}

Adams, Richard P. "Faulkner's Use of Motion as Metaphor." In Readings on William Faulkner. Edited by Clarice Swisher, 54-63. San Diego: The Greenhaven Press, 1998.

Bedell, George C. Kierkegaard and Faulkner: Modalities of Existence. Baton Rouge: Louisiana State University Press, 1972.

Blake, Nancy. "The Word as Truth or Delirium: Faulkner's As I Lay Dying." Revue belge de philologie et d'histoire, 63, no. 3 (1985): 554-553. DOI: 10.3406/rbph.1985.3513.

Boudraa, Nabil. "William Faulkner and the French-Speaking World." International Journal of Language and Literature, 2, no. 4 (2014): 109-122. DOI: 10.15640/ijll.v2n4a6.

Brooks, Cleanth. "Five Perspectives in The Sound and the Fury." In Readings on William Faulkner. Edited by Clarice Swisher, 104-115. San Diego: Greenhouse Press, 1998.

Cavell, Stanley. Disowning Knowledge in Seven Plays of Shakespeare. Massachusetts: Harvard University Press, 2003.

Church, Margaret. Time and Reality: Studies in Contemporary Fiction. Chapel Hill: The University of North Carolina Press, 1963.

Cohen, Philip, Fowler Doreen. "Faulkner's Introduction to The Sound and the Fury." American Literature, 62, no. 2 (June 1990): 267-283. DOI: 10.2307/2926916.

Cowley, Malcolm. "Introduction." In The Portable Faulkner, vi-xxxi. New York/London: Penguin Books, 2003.

Faulkner, William and Milton T. Inge. Conversations with William Faulkner. Jackson: University Press of Mississippi, 1999.

Faulkner, William, James B. Meriwether and Michael Millgate. Lion in the Garden: Interviews with William Faulkner. New York: Random House, 1968.

Harrington, Gary. Faulkner's Fables of Creativity: The Non-Yoknapatawpha Novels. Houndmills, Basingstoke/London: The Macmillan Press, 1990.

Kaufmann, Walter. Existentialism from Dostoevsky to Sartre. London: Penguin Group: England, 2004.

Kegley, Jacquelyne. "The End of the Road: The Death of Individualism." In Philosophy and Literature. Edited by Allen Phillips Griffiths, 115-135. Cambridge: Cambridge University Press, 1984. 
Kitcher, Philip. Deaths in Venice: The Cases of Gustav von Aschenbach. New York: Columbia University Press, 2013.

Kleinherenbrink, Arjen. “Time, Duration and Freedom - Bergson's Critical Move Against Kant.” Diametros, 2014, no. 39: 203-230. DOI: 10.13153/diam.39.2014.572.

Lamarque, Peter and Stein Haugom Olsen. Truth, Fiction, and Literature. A Philosophical Perspective. Oxford: Clarendon Press, 1994.

Murdoch, Iris. "Literature and Philosophy: A Conversation with Bryan Magee." In Existentialists and Mystics: Writings on Philosophy and Literature. Edited by Peter Conradi, 3-30. London: Penguin Books, 1999.

Nussbaum, Martha. Love's Knowledge. Oxford: Oxford University Press, 1990.

Read, Rupert. “Wittgenstein and Faulkner's Benjy: Reflections on and of derangement." In The Literary Wittgenstein. Edited by John Gibson and Wolfgang Huemer, 267-288. London: Routledge, 2004.

Reed, Joseph W. Jr. "Light in August." In Modern Critical Views: William Faulkner. Edited by Harold Bloom, 63-93. New York/Philadelphia: Chelsea House Publishers, 1986.

Sartre, Jean-Paul. We Have Only This Life to Live: The Selected Essays of Jean-Paul Sartre, 1939-1975. Edited by Ronald Aronson and Adrian van den Hoven. New York: New York Review Books, 2013.

Sartre, Jean-Paul. Existentialism and Humanism. Translated by Philip Mairet. London: Methuen, 2007.

Skirry, Justin. "Sartre on William Faulkner's Metaphysics of Time in The Sound and the Fury." Sartre Studies International 7, no. 2 (2001), 15-43. https://www.jstor.org/stable/23510954 (accessed January 10, 2018).

Slatoff, Walter J. Quest for Failure. Ithaca: Cornell University Press, 1960.

Sontag, Susan and Leland A. Poague. Conversations with Susan Sontag. Jackson: University Press of Mississippi, 1995.

Vickery, Olga W. "Language as Theme and Technique." In The Novels of William Faulkner: A Critical Interpretation, 266-282. Baton Rouge: Louisiana State University Press, 1964.

Volpe, Edmond L. A Reader's Guide to William Faulkner. New York: Syracuse University Press, 2003.

\section{Streszczenie}

\section{William Faulkner jako pisarz filozoficzny}

Artykuł podejmuje temat filozoficznych aspektów twórczości Williama Faulknera. Pierwsza część to próba zastanowienia się nad miejscem filozofii w literaturze. Przedstawione są różne stanowiska takich autorów jak Iris Murdoch, MarthaNussbaum, Philip Kitcher. Druga część artykułu koncentruje się na wybranych utworach Faulknera i jest próbą analizy jego twórczości pod kątem jego powiązań z filozofią. Główna teza artykułu stwierdza, że powieści 
Faulknera nie tylko podejmują fundamentalne kwestie filozoficzne, ale wciąż stanowią materiał dla współczesnego namysłu filozoficznego. Choć związek Faulknera z etyką, filozofią języka, metafizyką, czy wreszcie religią jest niezaprzeczalny, ten wątek $\mathrm{w}$ opracowaniach jego twórczości pozostaje wciąż marginalny. Rzadko akcentuje się również niezaprzeczalny wkład Faulknera do egzystencjalizmu i estymę, jaką darzyli go chociażby Sartre czy Camus. Artykuł jest próbą przywrócenia (jak nie ustanowienia) należnego Faulknerowi miejsca wśród innych pisarzy podejmujących w swojej twórczości kwestie filozoficzne.

Słowa kluczowe: literatura, filozofia, Faulkner, metafizyka, lingwistyka, etyka, religia, egzystencjalizm

\section{Zusammenfassung \\ William Faulkner als philosophischer Schriftsteller}

Der Artikel greift das Thema der philosophischen Aspekte im Schaffen von William Faulkner auf. Der erste Teil ist ein Versuch, über den Ort der Philosophie in der Literatur nachzudenken. Es werden unterschiedliche Meinungen solcher Autoren wie Iris Murdoch, Martha Nussbaum, Philip Kitcher dargestellt. Der zweite Teil des Artikels konzentriert sich auf ausgewählten Werken von Faulkner und bildet den Versuch, sein Schaffen unter dem Gesichtspunkt von seinen Beziehungen zur Philosophie zu betrachten. Die Hauptthese des Artikels lautet, dass Faulkners Romane nicht nur wesentliche philosophische Fragen aufgreifen, sondern auch selbst den Stoff zur gegenwärtigen philosophischen Reflexion anbieten. Obwohl die Beziehung Faulkners zur Ethik, Philosophie der Sprache, Metaphysik oder schließlich Religion unbestritten ist, bleibt dieser Faden in der Forschungsliteratur zu seinem Schaffen immer noch marginal. Ebenso selten wird der unbestreitbare Beitrag Faulkners zum Existentialismus sowie die Achtung betont, die ihm Sartre oder Camus entgegenbrachten. Der Artikel will Faulkner den ihm gebührenden Platz unter den Schriftstellern, die in ihrem Schaffen philosophische Fragen aufwerfen, wiederherstellen, wenn nicht neu bestimmen.

Schlüsselworte: Literatur, Philosophie, Faulkner, Metaphysik, Sprachwissenschaft, Ethik, Religion, Existentialismus

Informacje o Autorze:

IWONA SZYDŁOWSKA, mgr filologii angielskiej; doktorantka na Wydziale Nauk Społecznych Uniwersytetu Gdańskiego (Instytut Filozofii); adres do korespondencji: Wydział Nauk Społecznych, ul. Jana Bażyńskiego 4, 80-309 Gdańsk; e-mail: i.partyka@wp.pl

(cc) BY-NC-ND 